\title{
Leaf Area Estimation in Chamomile
}

\author{
Jocélia Rosa da Silva ${ }^{1}$, Arno Bernardo Heldwein ${ }^{1}$, Andressa Janaína Puhl ${ }^{1}$, Adriana Almeida do Amarante ${ }^{2}$, \\ Daniella Moreira Salvadé ${ }^{1}$, Cadmo João Onofre Gregory dos Santos ${ }^{1} \&$ Mateus Leonardi ${ }^{1}$ \\ ${ }^{1}$ Department of Plant Science, Federal University of Santa Maria, Santa Maria, Brazil \\ ${ }^{2}$ Department of Plant Science, Federal University of Pelotas, Pelotas, Brazil \\ Correspondence: Jocélia Rosa da Silva, Department of Plant Science, Federal University of Santa Maria, Santa \\ Maria, Rio Grande do Sul, Brazil. Tel: 55-55-981-478-611. E-mail: joceliarosa.s@gmail.com
}

Received: September 21, 2018

Accepted: November 11, 2018

Online Published: January 15, 2019

doi:10.5539/jas.v11n2p429

URL: https://doi.org/10.5539/jas.v11n2p429

\begin{abstract}
The knowledge of the variables specific leaf area and leaf area index is important for direct or indirect quantification of plant growth, development and yield. However, there is a lack of these information due to the difficulty in measuring the leaf area of chamomile. Measuring leaf area by direct methods, such as the use of leaf area integrator is a very laborious and time consuming activity because the plant has many leaves and with small size. The use of leaf dry matter is a promising variable for the leaf area estimation. As an important measure to evaluate plant growth, the present study aimed to obtain a model for chamomile leaf area estimation through leaf dry matter. The experiment was conducted in two sowing dates (March 18 and June 30, 2017) at different plant densities $\left(66,33,22,16,13,11\right.$ and 8 plants $\left.\mathrm{m}^{-2}\right)$. The leaves of chamomile plants were collected in the plant vegetative and reproductive phases. The leaf area determination was performed using the electronic integration method of leaf area. The specific leaf area was $133 \mathrm{~cm}^{2} \mathrm{~g}^{-1}$, with no differences between sowing dates, plant densities and phenological phases of plant collection. The leaf area measured with the electronic leaf area integrator exhibited high correlation with chamomile leaf dry matter and the resulting model of leaf area data by the integrator presented optimum performance. This model is indicated for leaf area determination of chamomile when there is availability of leaf dry matter data.
\end{abstract}

Keywords: Chamomilla recutita L., models, leaf area index, specific leaf area

\section{Introduction}

Among the medicinal plants grown in Brazil, chamomile (Chamomilla recutita L.) is the most prominent (Corrêa, Júnior, \& Scheffer, 2014). Besides the medicinal use, chamomile can also be used for the ornamentation and aromatization of environments and cosmetic purposes.

Growing demand for medicinal plants is observed with increased interest of the population in natural therapies through the use of medicinal plants and herbal products (Borsato et al., 2008). Consequently, this demand requires increments in crop production and yield. Thus, the research development that eases the compression of plant development and which are the factors that potentiate its productivity becomes paramount with greater requirements for medicinal products in the market. Information on specific leaf area (SLA) and leaf area index (LAI) are important for the quantification of growth, development, yield and its estimation through mechanistic modeling.

The SLA is characterized as the ratio between the light-catching surface of a leaf per unit of dry matter investment. Moreover, it is an important variable for the measurement of stresses that occur throughout the plant cycle and can be indirectly associated with the leaf useful life. Low SLA species invest more dry matter per leaf and often have low relative growth and net photosynthesis rates but have longer leaf longevity. Meanwhile, high SLA species invest less dry matter per leaf, growing rapidly and with shorter development cycle (Reich et al., 1992). However, the interception of solar radiation is directly conditioned by the LAI and the architecture of the plant canopy elements. Moreover, the photosynthetic process depends not only on the interception of light energy but also on the plant efficiency in its conversion into chemical energy (Taiz \& Zeiger, 2013).

Accurate LAI measurements are necessary to monitor the changes occurring in the plant throughout the development cycle and their relationship with the different biotic and abiotic factors. Therefore, this knowledge is especially useful with regard to the crop phytosanitary management. The knowledge of the leaf area is 
essential, considering that the LAI is the relation between the leaf area and the soil area occupied by the crop. There are many direct and indirect methods of measuring and/or estimating the plant leaf area. Measurements are taken directly on the leaf in direct methods. In the indirect methods, one determinant variable for the measured leaf area is used and significant correlation and models of estimation can be established. The leaf size, leaf disk and electronic leaf area integrators are among the most used and conventional methods for the leaf area determination.

Besides having many small leaves with less than five centimeters, chamomile has pinned leaves with linear segments, which hampers their measurement through the leaf dimensions. The measurement by the use of leaf area integrator has little use because it is an expensive and time-consuming activity. Another disadvantage is the high acquisition cost of the apparatus.

A simpler and faster alternative is the use of leaf dry matter to estimate leaf area, as performed for cotton by Monteiro et al. (2005) and cashew, soybeans and corn by Ramos et al. (2015), presenting generally stable coefficients. As leaf area is an important measure to evaluate plant growth, the present study aimed to obtain a model for chamomile leaf area estimation through leaf dry matter.

\section{Method}

One experiment with chamomile were carried out in an experimental area located at lat $29^{\circ} 43^{\prime} 23^{\prime \prime} \mathrm{S}$, long $53^{\circ} 43^{\prime} 15^{\prime \prime} \mathrm{W}$ and $95 \mathrm{~m}$ of altitude during the agricultural year of 2017. According to the Köppen climate classification, the climate of the region is Cfa fundamental type, characterized as humid subtropical with hot summer and normal rainfall distributed uniformly during the four seasons of the year, with an annual mean of $1,712 \mathrm{~mm}$ (Heldwein et al., 2009). The soil of the experimental area is classified as "Argissolo Vermelho Distrófico arênico" Paleudalf (Santos et al., 2013).

The sowing procedure of the experiments occurred on March 18 and June 30, 2017, using the cultivar Mandirituba, with seeds obtained from growers in the municipality of Mandirituba-PR. Sowing was carried out in rows, after previous plowing and harrowing of the area, aiming to provide better initial plant development conditions. The fertilization was performed based on the soil analysis and the chamomile crop requirements (CQFS-RS/SC, 2004). The only cultural treatment performed was manual weeding, which was carried out throughout the crop cycle in order to avoid damage caused by weed competition. There was no incidence of pests and diseases during the experiment, requiring no control interventions. Complementary irrigation was performed by dripping in the experimental area in order to avoid the influence of water deficit stress on chamomile crop development.

After plant emergence, thinning was carried out in the two areas with the aim of applying the treatments of different plant densities. The adopted spacing was $30 \mathrm{~cm}$ between rows and 5, 10, 15, 20, 25, 30 and $40 \mathrm{~cm}$ between plants, totaling the plant densities of $66,33,22,16,13,11$, and 8 plants $\mathrm{m}^{-2}$, respectively. In each experimental area, the seven plant densities were allocated with four replicates, totaling 28 experimental units per sowing date. Each experimental unit consisted of 10 rows of plants with dimensions of $3 \times 3 \mathrm{~m}$, covering a total area of $9.0 \mathrm{~m}^{2}$ and a useful area of $4 \mathrm{~m}^{2}$.

For the leaf area analyzes, six collects were taken in each sowing date and two plants per plot were collected at each evaluation. Furthermore, the six collects were divided in three during the vegetative phase and the other three in the reproductive phase.

The experiment was arranged in a trifactorial scheme, using a completely randomized design with four replicates. The factor A was composed by the sowing dates (March 18 and June 30, 2017), the factor B by the seven different plant densities $\left(66,33,22,16,13,11\right.$ and 8 plants $\left.\mathrm{m}^{-2}\right)$ and the factor $\mathrm{C}$ by the plant development stages (vegetative and reproductive). Therefore, a total of 336 chamomile plants were collected for the analysis of leaf area and its relation with the leaf dry matter.

Leaves were removed from the plants after the collection and the number of leaves of each analyzed sample per plant ranged from ten to all plant leaves. Thereby, the leaves of each sample were randomly taken from the plant, with different sizes and locations in the plant. Leaf area determination was performed using the electronic integration method of leaf area.

The leaf area integrator Li-3000 model from Liquor was used for leaf area measurement. Each leaf was individually passed through the electronic sensor of rectangular approximation, which provides a resolution of 1 $\mathrm{mm}^{2}$. After leaf area determination of the chamomile leaves, the leaf samples of each plant were conditioned in paper bags and dried in a $60{ }^{\circ} \mathrm{C}$ ventilated oven until the samples obtained constant weight. Subsequently, the 
dried leaves were weighed using a precision scale, with a resolution of $0.001 \mathrm{~g}$, aiming to determine the leaf dry matter of the samples with measured area.

The calculation of the specific leaf area (leaf area $\left(\mathrm{cm}^{2}\right)$ /leaf dry matter $(\mathrm{g})$ ) was based on the dry matter data of leaf samples and the respective leaf area measured by the leaf area integrator. The normality of the errors of the data was tested by the Shapiro-Wilk test and the homogeneity of the variances by the Bartlett test, both using the Action ${ }^{\circledR} 2.5$ software. In order to meet the mathematical model assumptions, the Box-Cox methodology was used for the appropriate transformation. The means presenting significance were compared by the Scott-Knott test at $p \leq 0.05$ of probability, using the Sisvar ${ }^{\circledR}$ software (Ferreira, 2011). The means of the transformed variables were presented with the original values.

For the estimation of the leaf area of the camomile, half of the data were used to fit the model and the other half to evaluate the model. For the adjustment of the model, a comparison was made between the variables dry mass of the leaves and the leaf area obtained by the integrator, through a linear regression. With the other half of the data the model evaluation was performed, comparing the observed leaf area data measured by the leaf area integrator and the respective data estimated by the model from the leaf area, generated through linear regression.

The following statistical indicators were used to evaluate the model performance: mean absolute error (MAE); coefficient of determination $\left(\mathrm{R}^{2}\right)$, root mean square error (RMSE), Willmott's index of agreement (d) and confidence index (c), determined according to Camargo and Sentelhas (1997).

\section{Results}

The values of the specific leaf weight calculated through the leaf area measured by the leaf area integrator method did not present a significant statistical difference when subjected to the analysis of variance for the tested factors (sowing date, plant density and phenological phase) and there was also no interaction between the factors (Table 1). As there was no significant difference between the specific leaf areas calculated from the leaf area obtained by the integrator with a coefficient of variation of $9 \%$, we can infer that the mean specific leaf weight of $133 \mathrm{~cm}^{2} \cdot \mathrm{g}^{-1}$ can be used for all the tested treatments.

A leaf area model was obtained considering the leaf dry matter because there was no difference between the SLA, i.e., the relation between leaf area and leaf dry matter, among the different tested treatments.

A model of leaf area estimation for chamomile was obtained through the linear regression model between leaf dry matter and leaf area measured by the leaf area integrator (Figure 1). The model exhibited high coefficient of determination, indicating high correlation between leaf area and leaf dry matter. Therefore, the chamomile leaf area determination using the leaf dry matter is a viable alternative.

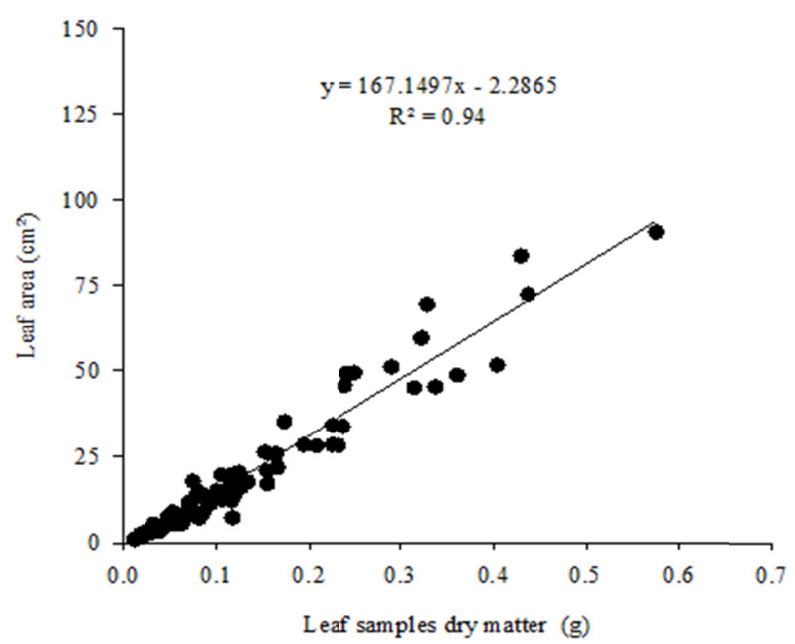

Figure 1. Linear regression model between the chamomile leaf samples dry matter $(\mathrm{x})$ and its respective leaf area

(y) determined by the electronic integrator of leaf area

After obtaining the model of leaf area estimation, model testing was performed by comparing the estimated leaf area with the leaf area obtained by electronic integration and confirmed the model quality. The estimated leaf area with the equation 1 exhibited high correlation with the observed leaf area, presenting low data dispersion, 
high $\mathrm{R}^{2}$, approximation with the line 1:1 (Figure 2), and high estimate precision. These statistics confirmed that the model has a high estimate precision but it tends to underestimate leaf area values larger than $40 \mathrm{~cm}^{2}$ in the order of $12 \%$.

$$
L A=(167.1497 \times L D M)-2.2865
$$

where, LA is the leaf area estimation $\left(\mathrm{cm}^{2}\right)$ and LDM is the leaf dry matter $(\mathrm{g})$.

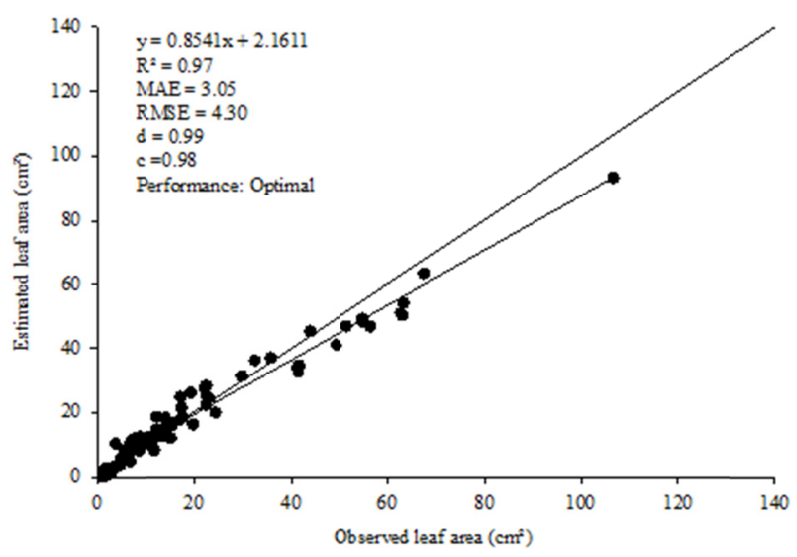

Figure 2. Relation of the leaf area determined by the electronic integrator of leaf area with the estimated leaf area from the leaf dry matter, using the respective linear regression model between the dry matter and the leaf area obtained with an independent database along with the respective coefficient of determination $\left(\mathrm{R}^{2}\right)$, Mean Absolute Error $\left(\mathrm{MAE}, \mathrm{cm}^{2}\right)$, Root Mean Square Error (RMSE, $\left.\mathrm{cm}^{2}\right)$, Willmott's index of agreement (d), confidence index (c), and rating of model performance

The MAE and RMSE obtained from the relation between the data of estimated leaf area by the model and those observed by the leaf area integrator (Figure 2) are considered lower. The Willmott's index of agreement (d) and the confidence index (c), which represent the accuracy and precision of the method, also exhibited a clear agreement between the data observed and estimated by the model. Moreover, the model performance was classified as optimal according to the classification of Camargo and Sentelhas (1997).

\section{Discussion}

According to Pereira and Machado (1987), the SLA remains constant or has small variation throughout the crop growth cycle. Commonly, there is a difference in crop leaf area when the crop is submitted to stressful abiotic conditions, such as inadequate conditions of light incidence, fertility and soil water. However, the difference in SLA is not observed routinely in response to adopted crop management techniques such as plant density (Galmes et al., 2005; Dwyer et al., 2014). Changes caused by modification in the meteorological variables resulting from the sowing date can cause alteration in the SLA, mainly by the sudden change in the radiation balance and rainfall, seeking to adapt and better exploit the environment and the available resources (Dwyer et al., 2014). Based on the irrigation system installed, well-distributed rainfall throughout the year in experimental area and solar radiation within the limits required for the full crop growth (Heldwein et al., 2009), we inferred that there was no environmental change related to these variables or significant plant stresses sufficient to cause a difference between the plant SLA between the two sowing dates.

Leaf area determination through the electronic integrator is very laborious and time consuming because chamomile has small and numerous leaves. Therefore, the application of models that include the leaf dry matter as an independent variable is a great alternative. Results and statistics obtained with the LA estimation model based on the leaf dry matter were satisfactory, significantly reducing labor and justifying its general use. In addition, the effects of LAI differences are evaluated in most studies of growth analysis and plant competition capacity and systematic LA determination errors are proportional to all treatments.

The generated model with the leaf area measured by the leaf area integrator obtained optimum overall performance. Therefore, the model can be used to determine the chamomile leaf area as a function of the leaf dry matter. The model use will reduce the time and labor of leaf area determination without significant quality decrease in the obtained leaf area data. 


\section{Conclusions}

The chamomile specific leaf area did not differ between sowing dates, plant densities and phenological phases of plant collection. The specific leaf area of chamomile was $133 \mathrm{~cm}^{2} \mathrm{~g}^{-1}$.

The leaf area measured by the electronic integrator exhibited high correlation with the chamomile leaf dry matter.

The model resulting from leaf area data measured by the electronic integrator presented optimum performance, being indicated for the chamomile leaf area determination when there is available leaf dry matter data.

\section{Acknowledgements}

We thank the National Council for Scientific and Technological Development (CNPq) and the Coordination for the Improvement of Higher Education Personnel (CAPES) for granting scholarships and scientific initiation.

\section{References}

Borsato, A. V., Doni-Filho, L., Côcco, L. C., \& Paglia, E. C. (2008). Rendimento e composição química do óleo essencial da camomila [Chamomilla recutita (L.) Rauschert] extraído por arraste de vapor d'água, em escala comercial. Ciências Agrárias, 29, 129-136. https://doi.org/10.5433/1679-0359.2008v29n1p129

Camargo, A. D., \& Sentelhas, P. C. (1997). Avaliação do desempenho de diferentes métodos de estimativa da evapotranspiração potencial no Estado de São Paulo, Brasil. Revista Brasileira de Agrometeorologia, 5, 89-97.

Corrêa Júnior, C., \& Scheffer, M. C. (2014). As plantas medicinais, aromáticas e condimentares e a agricultura familiar. Horticultura Brasileira, 32, 376. https://doi.org/10.1590/S0102-05362014000300023

CQFS (Comissão de Química e Fertilidade do Solo). (2004). Manual de adubação e calagem para os Estados do Rio Grande do Sul e de Santa Catarina (10th ed.). Porto Alegre: Comissão de Química e Fertilidade do Solo-RS/SC.

Dwyer, J. M., Hobbs, R. J., \& Mayfield, M. M. (2014). Specific leaf area responses to environmental gradients through space and time. Ecology, 95, 399-410. https://doi.org/10.1890/13-0412.1

Ferreira, D. F. (2011). Sisvar: Um sistema computacional de análise estatística. Ciência e Agrotecnologia, 35, 1039-1042. https://doi.org/10.1590/S1413-70542011000600001

Galmes, J., Cifre, J., Medrano, H., \& FLexas, J. (2005). Modulation of relative growth rate and its components by water stress in Mediterranean species with different growth forms. Oecologia, 145, 21-31. https://doi.org/10.1007/s00442-005-0106-4

Heldwein, A. B., Buriol, G. A., \& Streck, N. A. A. (2009). O clima de Santa Maria. Ciência \& Ambiente, 38, 43-58.

Monteiro, J. E. B. A., Sentelhas, P. C., Chiavegato, E. J., Guiselini, C., Santiago, A. V., \& Prela, A. (2005). Estimação da área foliar do algodoeiro por meio de dimensões e massa das folhas. Bragantia, 64, 15-24. https://doi.org/10.1590/S0006-87052005000100002

Pereira, A. R., \& Machado, E. C. (1987). Análise quantitativa do crescimento de comunidades vegetais. Boletim Técnico do Instituto Agronômico. Campinas, 114, 1-33.

Ramos, F. T., Ferreira, L. S., Pivetta, F., \& Maia, J. C. S. (2015). Área do limbo foliar de diferentes plantas estimada por medidas lineares e matéria seca, calibradas com o software IMAGEJ. Interciencia, 40, 570-575.

Reich, P. B., Walters, M. B., \& Ellsworth, D. S. (1992). Leaf life-span in relation to leaf, plant, and stand characteristics among diverse ecosystems. Ecological Monographs, 62, 365-392. https://doi.org/10.230 $7 / 2937116$

Santos, H. G., Jacomine, P. K. T., Anjos, L. H. C., Oliveira, V. A., Oliveira, J. B., Coelho, M. R., ... Cunha, T. J. F. (2013). Sistema brasileiro de classificação de solos (3rd ed.). Brasília: Embrapa.

Taiz, L., \& Zeiger, E. (2013). Fisiologia vegetal. Porto Alegre: Artmed. 


\section{Appendix A}

Analysis of variance of the specific leaf area $\left(\mathrm{cm}^{2} \mathrm{~g}^{-1}\right)$ of chamomile conducted in two sowing dates, seven plant densities and collected in two development stages

\begin{tabular}{llllll}
\hline Source of variation & DF & SS & MS & Fc & Pr $>$ Fc \\
\hline Sowing dates (A) & 1 & 209.51 & 209.51 & 1.466 & 0.228 \\
Development stages (D) & 1 & 0.081 & 0.081 & 0.001 & 0.981 \\
Plant densities (E) & 6 & 1524.01 & 254.00 & 1.778 & 0.108 \\
$\mathrm{~A} \times \mathrm{D}$ & 1 & 223.79 & 223.78 & 1.566 & 0.213 \\
$\mathrm{~A} \times \mathrm{E}$ & 6 & 1220.49 & 203.41 & 1.424 & 0.210 \\
$\mathrm{D} \times \mathrm{E}$ & 6 & 1109.33 & 184.89 & 1.294 & 0.264 \\
$\mathrm{~A} \times \mathrm{D} \times \mathrm{E}$ & 6 & 878.35 & 146.39 & 1.024 & 0.412 \\
Residue & 140 & 200004.81 & 142.89 & & \\
Coefficient of variation (\%) & 9.0 & & & & \\
General mean & 132.96 & & & &
\end{tabular}

Note. $\mathrm{DF}=$ degrees of freedom; $\mathrm{SS}=$ sum of suares; $\mathrm{MS}=$ mean square; $\mathrm{Fc}=\mathrm{F}$ calculated; $\mathrm{Pr}>\mathrm{Fc}=$ Probability of F-tabulated is greater than Fc.

\section{Copyrights}

Copyright for this article is retained by the author(s), with first publication rights granted to the journal.

This is an open-access article distributed under the terms and conditions of the Creative Commons Attribution license (http://creativecommons.org/licenses/by/4.0/). 